OPEN ACCESS

Edited by:

Vimala D. Nair,

University of Florida, United States

Reviewed by:

Peter Thorburn,

Commonwealth Scientific

and Industrial Research Organisation

(CSIRO), Australia

Leon Etienne Parent,

Laval University, Canada

*Correspondence:

Kamaljit Banger

kamal.banger@gmail.com

Specialty section:

This article was submitted to Agroecology and Land Use Systems,

a section of the journal

Frontiers in Plant Science

Received: 04 April 2017

Accepted: 05 July 2017

Published: 28 July 2017

Citation:

Banger K, Yuan M, Wang J,

Nafziger ED and Pittelkow CM (2017)

A Vision for Incorporating

Environmental Effects into Nitrogen Management Decision Support Tools

for U.S. Maize Production.

Front. Plant Sci. 8:1270.

doi: 10.3389/fpls.2017.01270

\section{A Vision for Incorporating Environmental Effects into Nitrogen Management Decision Support Tools for U.S. Maize Production}

\author{
Kamaljit Banger ${ }^{1 *}$, Mingwei Yuan', Junming Wang ${ }^{2}$, Emerson D. Nafziger ${ }^{1}$ and \\ Cameron M. Pittelkow ${ }^{1}$
}

\begin{abstract}
${ }^{1}$ Department of Crop Sciences, University of Illinois at Urbana-Champaign, Champaign, IL, United States, ${ }^{2}$ Climate and Atmospheric Science Section, Illinois State Water Survey of the Prairie Research Institute, University of Illinois at Urbana-Champaign, Champaign, IL, United States
\end{abstract}

Meeting crop nitrogen $(\mathrm{N})$ demand while minimizing $\mathrm{N}$ losses to the environment has proven difficult despite significant field research and modeling efforts. To improve $\mathrm{N}$ management, several real-time $\mathrm{N}$ management tools have been developed with a primary focus on enhancing crop production. However, no coordinated effort exists to simultaneously address sustainability concerns related to $\mathrm{N}$ losses at field- and regional-scales. In this perspective, we highlight the opportunity for incorporating environmental effects into $\mathrm{N}$ management decision support tools for United States maize production systems by integrating publicly available crop models with grower-entered management information and gridded soil and climate data in a geospatial framework specifically designed to quantify environmental and crop production tradeoffs. To facilitate advances in this area, we assess the capability of existing crop models to provide in-season $\mathrm{N}$ recommendations while estimating $\mathrm{N}$ leaching and nitrous oxide emissions, discuss several considerations for initial framework development, and highlight important challenges related to improving the accuracy of crop model predictions. Such a framework would benefit the development of regional sustainable intensification strategies by enabling the identification of $\mathrm{N}$ loss hotspots which could be used to implement spatially explicit mitigation efforts in relation to current environmental quality goals and real-time weather conditions. Nevertheless, we argue that this longterm vision can only be realized by leveraging a variety of existing research efforts to overcome challenges related to improving model structure, accessing field data to enhance model performance, and addressing the numerous social difficulties in delivery and adoption of such tool by stakeholders.

Keywords: crop models, corn, in-season nitrogen management, leaching, nutrient recommendation

\section{INTRODUCTION}

Managing nitrogen $(\mathrm{N})$ on over 130 million ha of cropland is critical for sustainable food production due to the large impact of $\mathrm{N}$ fertilizer on farm profits and environmental health (Anderson et al., 2008; Howarth, 2008). In Corn Belt of the United States, only $37 \pm 30 \%$ of applied $\mathrm{N}$ is utilized by the crop (Cassman et al., 2002), with the remaining portion being susceptible to 
environmental losses. Excessive $\mathrm{N}$ leaching from corn fields is a leading source for degradation of water resources (Goolsby and Battaglin, 2001; Ewing and Runck, 2015) while N fertilizer inputs are also linked to increased nitrous oxide $\left(\mathrm{N}_{2} \mathrm{O}\right)$ emissions (USEPA, 2014). Therefore, farmers are increasingly faced with the challenge of increasing yields and maximizing farm profits while minimizing negative environmental tradeoffs to meet social demands being placed on agriculture.

Weather patterns in a growing season are a primary factor controlling crop uptake and environmental $\mathrm{N}$ losses (Randall and Mulla, 2001). Christianson and Harmel (2015) recently evaluated 40 years of research and found strong relationships between precipitation and $\mathrm{N}$ leaching losses, as well as higher crop yields in years with adequate precipitation. In contrast, drought conditions can reduce plant growth and $\mathrm{N}$ transport to plant roots, resulting in low $\mathrm{N}$ recovery efficiency in dry years (Kim et al., 2008). Interestingly, these weather effects are modified by soil properties and agronomic management, which often result in the development of hotspots of relatively higher $\mathrm{N}$ loss (Sogbedji et al., 2001; Kurunc et al., 2011; Tremblay et al., 2012). Thus, it is critical to develop decision support tools that can predict crop yields, soil $\mathrm{N}$ supply, and environmental $\mathrm{N}$ loss to assist farmers in optimizing $\mathrm{N}$ management in United States corn production systems. With the aim of adjusting sitespecific $\mathrm{N}$ management decisions in the growing season, several existing approaches include soil nitrate tests, sensor based tools, and crop-based diagnostics (Scharf, 2015). Soil nitrate tests are conducted to quantify residual $\mathrm{N}$ availability from previous crop as well as to estimate soils $\mathrm{N}$ supplying capacity in the corn growing season (Bundy and Malone, 1988; Blackmer et al., 1989; Magdoff, 1991; Schmitt and Randall, 1994). Sensor-based tools include chlorophyll meters (CM) and remote sensing approaches (Shanahan et al., 2008; Ziadi et al., 2008; Tremblay et al., 2011; Yuan et al., 2016). Yet, CM readings show wide variations with respect to cultivars, growth stages, measurement methods, and agronomic practices (Debaeke et al., 2006, 2012; Ziadi et al., 2008). Another practical problem associated with the use of soil nitrate tests and CMs is the time required to obtain representative samples, particularly for larger farms. Remote sensing techniques including hyperspectral imagery can be powerful tools to assess chlorophyll content, biomass, and other biochemical and biophysical properties (Yuan et al., 2016). However, remote sensing methods have limitations resulting in low adoption by farmers including the high cost of sensors and the degree of computer and geospatial skills required to process grid based data, and the need for continuous calibration against soil tests.

To overcome these limitations, a number of site-specific fertilizer recommendation tools based on crop models have recently been developed. For example, Adapt- $\mathrm{N}$ which was developed by Cornell University and later commercialized by Agronomic Technology Corporation, is a tool which integrates daily weather, soils data, and field-specific agronomic management information to estimate $\mathrm{N}$ recommendations for corn production (van Es et al., 2002). Recently, in 113 on-farm strip trials in Iowa and New York, Adapt-N was found to reduce $\mathrm{N}$ rates and $\mathrm{N}$ losses by 34 and 38\%, respectively, relative to farmers' practices with no significant difference in yield (Sela et al., 2017). In similar lines, The Climate Corporation has developed FieldView, an online tool capable of providing $\mathrm{N}$ recommendations for corn farmers. To our knowledge, the effectiveness of FieldView in maintaining crop yield or reducing environmental $\mathrm{N}$ losses has not been assessed. The release of these products represents a breakthrough for this field, with potentially large benefits for crop production.

Despite these promising advances, in this Perspective paper we argue that if these new technologies are to have broader sustainability impacts, several key issues need to be addressed. First, the underlying source codes for both Adapt-N and FieldView are not available in the public domain, which hinders other researchers from improving and integrating new mechanisms associated with soil $\mathrm{N}$ supply, crop growth, and environmental loss. For instance, Moore et al. (2014) suggested that quality assurance processes, documentation procedures, and access to model source codes are important aspects while selecting crops models for assessing proposed greenhouse gas abatement methodologies in Australian agriculture. Moreover, previous research has suggested that there are number of non-technological factors such as broad social learning for participatory development of extension specialists, farmers, and scientists to ensure effective adoption of such decision support tools by farmers (Jakku and Thorburn, 2010). Therefore, to enhance the engagement of the broader research community in the development and robust validation of such tools, it is preferable that publicly available models are used rather than commercial products. Second, when making $\mathrm{N}$ management decisions, farmers are understandably driven by economic considerations, thus current tools are focused on increasing soil $\mathrm{N}$ supply and yields with little emphasis on environmental effects. To encourage use by multiple stakeholders, it is advisable that $\mathrm{N}$ loss estimates are converted into actionable knowledge for farmers, for example by providing an interpretation of values with respect to established targets for a farm or region (Ledgard et al., 1999; Cox et al., 2008; Wheeler et al., 2008). Third, and perhaps most importantly, no coordinated effort exists to leverage field-scale $\mathrm{N}$ loss estimates to inform the development of regional sustainable intensification strategies. If such tools were to be adopted by farmers at a sufficient scale, information that is not presently available would become available to support novel geospatial assessments of tradeoffs between crop yields and $\mathrm{N}$ losses, greatly improving our ability to develop targeted mitigation efforts.

Here we address three areas requiring further attention in order for $\mathrm{N}$ management decision support tools to systematically improve environmental sustainability outcomes: the suitability of current, publicly available crop models, initial considerations in geospatial framework development, and important challenges related to model improvements. 


\section{TURNING AVAILABLE CROP MODELS INTO REAL-TIME N MANAGEMENT TOOLS}

We reviewed the literature to assess the capability of existing publicly available crop models to serve as in-season $\mathrm{N}$ management tools for farmers. A total of 12 crop models were assessed according to their current ability to (1) incorporate realtime weather data and provide in-season $\mathrm{N}$ recommendations, and (2) simultaneously estimate crop yields and negative environmental tradeoffs related to $\mathrm{N}$ management (Table 1).

Several existing crop models that are capable of simulating both crop growth and soil $\mathrm{N}$ transformations could potentially be used to provide $\mathrm{N}$ recommendations in the growing season. However, only Maize-N and QUEFTS are currently used for in-season N recommendations (Janssen et al., 1990; Setiyono et al., 2011). Maize-N combines the Hybrid-Maize model for estimating yield (Yang et al., 2004) with a soil organic matter (SOM) mineralization scheme (Yang and Janssen, 2000) and empirical method for predicting the response of maize yield to $\mathrm{N}$ uptake (Setiyono et al., 2011). QUEFTS was primarily developed for tropical conditions with limited application in the United States Midwest. The model recommendations are based on soil fertility status and economic profitability while fewer details are provided on mechanisms controlling the fate of soil $\mathrm{N}$ within a growing season.

When models were assessed against the second selection criteria, seven had the ability to simultaneously simulate both grain yield and environmental loss in response to $\mathrm{N}$ fertilizer use (Li et al., 1992; Abrahamsen and Hansen, 2000; Jones et al., 2003; Stockle et al., 2003; Xiong et al., 2008; Holzworth et al., 2014). Four models (Maize-N, NCSOIL, QUEFTS, and SoilN) do not incorporate algorithms for estimating denitrification and leaching losses of fertilizer applied N (Molina et al., 1983; Bergstrom et al., 1991; Hanson et al., 1998; Wang et al., 2012). The EPIC model, which is primarily designed to predict the effects of soil erosion on crop productivity, can simulate leaching but not denitrification losses (Wang et al., 2012). As no publicly available models met both criteria, models that estimated environmental tradeoffs are considered here to be the most promising candidates for tool development, assuming they could be integrated with real-time weather as discussed below. Two critical points not considered in this review require further attention. First, important differences may exist regarding the relative capability of these models in predicting $\mathrm{N}$ losses vs. crop growth processes and yield (Bassu et al., 2014; Muller et al., 2017). To serve as an indication of which models have a stronger focus on simulating crop growth processes and yield, Table $\mathbf{1}$ includes a column noting whether individual cultivars can be specified as an input. Similarly, there is an important difference between whether a model is capable of predicting an output (such as crop yield or $\mathrm{N}$ leaching losses) and how extensively the model has been evaluated in predicting an output under a variety of conditions. These aspects would need to be evaluated prior to model selection for geospatial tool development.
With a long-term vision of creating in-season $\mathrm{N}$ management decision support tools, we now discuss several important attributes to consider for geospatial framework development for corn production systems of the United States (Figure 1). The aim of our proposed tool would be to estimate crop yield and environmental loss in the growing season and identify site-specific actions for farmers in the regional sustainability context (Moore et al., 2014). The first step would be designing a user interface by integrating the selected crop model with daily weather, site-specific soils, information and hydrological data from United States Geological Survey (USGS). For the models reviewed above, the majority of previous modeling applications have been conducted retrospectively at individual sites. Since we are unaware of any publicly available model-based framework linking weather, soils, and farmer management to estimate $\mathrm{N}$ losses in real-time in United States maize production systems, a real-time modeling interface would represent an important technological advance in this area, with farmers being able to provide minimal inputs including geographical location and relevant crop management practices, while the user interface would automatically incorporate other necessary input data from public resources (Melkonian et al., 2008).

A second consideration would be to transform model outputs into user-friendly sustainability indices for minimizing $\mathrm{N}$ leaching and $\mathrm{N}_{2} \mathrm{O}$ emissions associated with $\mathrm{N}$ management for corn production systems of the United States. Currently, public and private models do not provide a context for interpreting the magnitude of $\mathrm{N}$ loss estimates, thus an opportunity exists to assess whether estimates require action in relation to regional environmental quality goals. For example, if tool developments were focused on $\mathrm{N}$ loss to waterbodies in the United States Midwest, watershed-specific numeric nutrient criteria (if available) or regional targets set by United States Environmental Protection Agency (USEPA) could act as thresholds for maximum $\mathrm{N}$ losses from farmland (INLRS, 2016). The geospatial framework should be designed to account for farm location in addition to management, as some farms contribute disproportionately higher $\mathrm{N}$ loads to waterbodies depending on their geographical location, stream network, and presence of riparian buffer zones (Batie, 1985). It has also been shown that the effectiveness of various practices to control $\mathrm{N}$ pollution can vary widely across different geographical locations in a watershed (Arbuckle, 2013). Recently, Tomer et al. (2013) developed a rigorous framework for identifying the most effective site-specific practices for reducing nutrient losses within watersheds at Hydrological Unit Codes (HUC-12). This method or similar approaches could be adapted to serve as a foundation for prioritizing the effectiveness of practices in future tools, recognizing that the resolution of analysis would need to be adjusted to match the goals of the tool (in this case a finer resolution would be needed to estimate farm-level $\mathrm{N}$ pollution). Regarding air quality impacts, though several models can predict denitrification loss, only four models (APSIM, Cropsyst, DAYCENT, DNDC) have algorithms to estimate $\mathrm{N}_{2} \mathrm{O}$ emissions (Table 1). As a first step, mechanisms for separating $\mathrm{N}_{2} \mathrm{O}$ emissions from denitrification loss should be incorporated and robustly tested against field datasets for these models. Unlike 
TABLE 1 | Status of the current public available crop models to estimate crop-growth and environmental tradeoffs.

\begin{tabular}{|c|c|c|c|c|c|c|c|c|}
\hline \multirow[t]{2}{*}{ Model } & \multirow[t]{2}{*}{ Spatial scale } & \multirow{2}{*}{$\begin{array}{c}\text { Crop } \\
\text { growth }\end{array}$} & \multirow{2}{*}{$\begin{array}{l}\text { Cultivars } \\
\text { within } \\
\text { a crop }\end{array}$} & \multicolumn{4}{|c|}{ Environmental tradeoffs } & \multirow{2}{*}{$\begin{array}{l}\text { Ability to predict both } \\
\text { crop yield and } \\
\text { environmental loss? }\end{array}$} \\
\hline & & & & Denitrification & $\mathrm{N}_{2} \mathrm{O}$ emissions & Volatilization & Leaching & \\
\hline APSIM & Point & + & + & + & + & - & + & + \\
\hline Cropsyst & Point & + & + & + & + & + & + & + \\
\hline DAISY & Point & + & - & + & - & + & + & + \\
\hline DAYCENT & Point & + & - & + & + & + & + & + \\
\hline DNDC & Point and regional & + & - & + & + & + & + & + \\
\hline DSSAT & Point & + & + & + & - & + & + & + \\
\hline EPIC & Watershed & + & - & + & - & + & + & - \\
\hline Maize-N & Point & + & - & - & - & + & - & - \\
\hline NCSOIL & Point & - & - & - & - & - & - & - \\
\hline QUEFTS & Point & + & + & - & - & + & - & - \\
\hline RZWQM & Point & + & + & + & - & + & + & + \\
\hline SoilN & Point & - & - & - & - & + & + & - \\
\hline
\end{tabular}

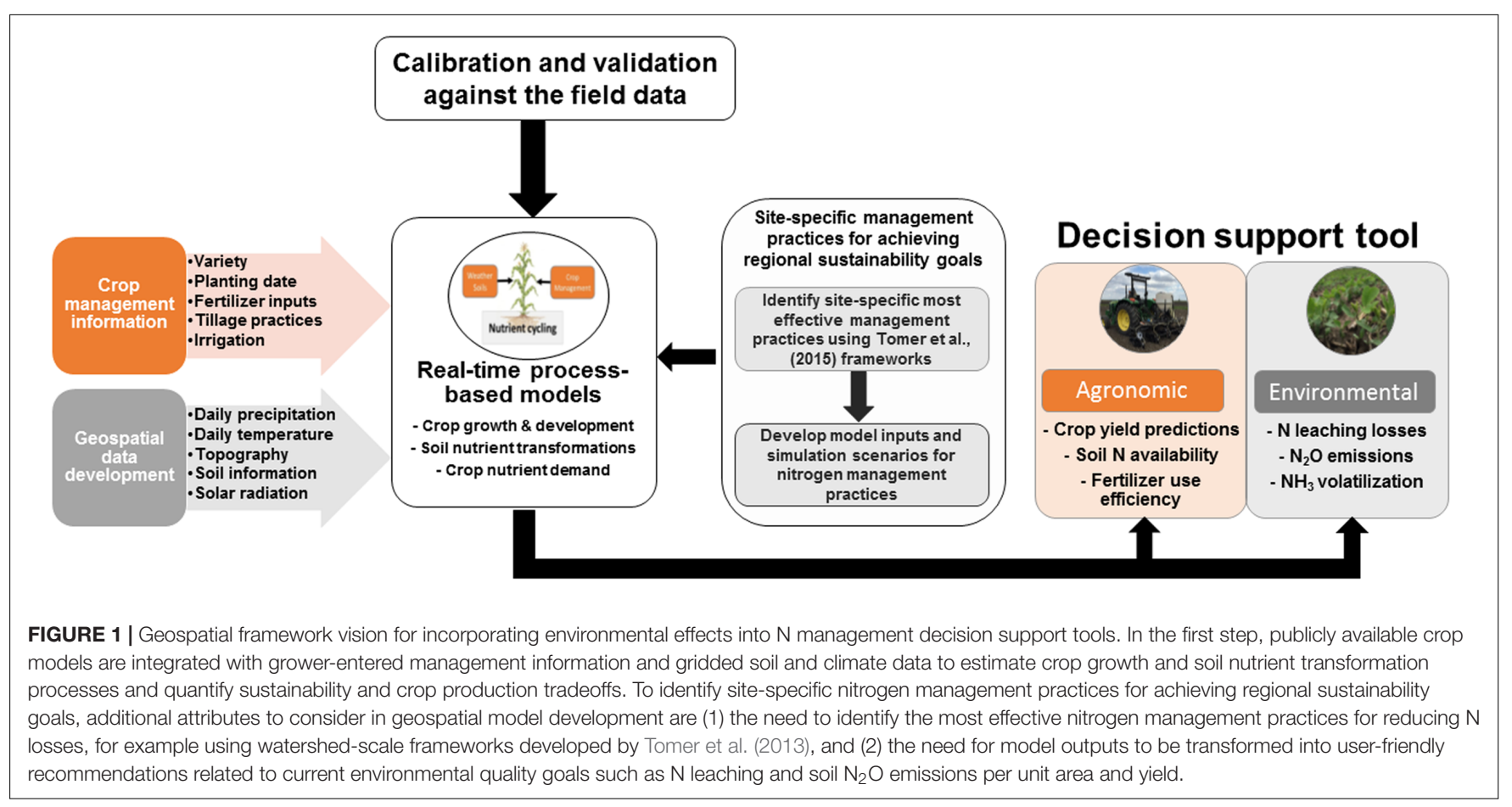

$\mathrm{N}$ leaching loss, less information is available to relate $\mathrm{N}_{2} \mathrm{O}$ emission estimates to regional environmental quality targets. As a starting point, crop-specific emissions factors would likely need to act as a reference for farmers, with model-estimated $\mathrm{N}_{2} \mathrm{O}$ emissions being compared to crop-specific emission factors available from public databases such as IPCC or the United States EPA (IPCC, 2006). Given the importance of agricultural $\mathrm{N}_{2} \mathrm{O}$ emissions for climate change, in the longer-term it would be desirable for the proposed $\mathrm{N}$ management tool to provide options regarding the effectiveness of formulations, timings, rate, and slow release fertilizers on $\mathrm{N}_{2} \mathrm{O}$ emissions and crop yields. Similarly, various efforts are underway to establish better regionand crop-specific $\mathrm{N}_{2} \mathrm{O}$ mitigation targets (Decock et al., 2015), and these values could be incorporated as they become available.
A third consideration would be to aggregate simulations for field-level crop production and environmental outcomes to larger spatial domains that have been determined to be important for policy-making and strategic investments in agriculture (Grassini et al., 2017). Assuming sufficient farmer participation and adequate spatial coverage, a novel outcome of this framework would be a database containing realtime, spatially explicit estimates of crop growth, nutrient uptake, $\mathrm{N}$ leaching, and $\mathrm{N}_{2} \mathrm{O}$ emissions for a given region. While watershed- or ecosystem-scale models have been used in this regard, they often rely on assumptions of uniform crop management within a watershed, thus a strength of the proposed framework would be high-resolution $\mathrm{N}$ loss simulations based on accurate crop management information. 
This type of geospatial information would help advance sustainable intensification planning, which is in part limited due to poor data availability, preventing assessments of how $\mathrm{N}$ management simultaneously impacts yield and environmental outcomes. Real-time simulations would also allow the database to be used for identifying $\mathrm{N}$ loss hotspots and developing targeted mitigation strategies within a season. Spatial patterns of $\mathrm{N}$ loss vary annually, largely according to precipitation. Morever, understanding these patterns will become increasingly important under climate change in the future, as more variable and severe precipitation events are expected.

\section{CHALLENGES}

We recognize there are a number of major limitations that need to be addressed before $\mathrm{N}$ recommendation tools can be developed and employed with an acceptable level of confidence (Asseng et al., 2013; Wallach and Thorburn, 2014). Current models may lack accurate mechanistic processes and model parameters for predicting environmental $\mathrm{N}$ losses and crop yields (Brilli et al., 2017). For example, an important process regulating soil $\mathrm{N}$ availability is SOM mineralization which is highly uncertain in existing models (Benbi and Richter, 2002). Thus, a major challenge is to improve SOM mineralization, with one option being robust model validations of soil respiration in response to environmental factors using field data (Todd-Brown et al., 2013; Tian et al., 2015) A second challenge would be to improve crop growth and development processes (Asseng et al., 2013), particularly the incorporation of cultivars (Archontoulis et al., 2014). In a multi-model intercomparison study, Asseng et al. (2013) described that future climate change impacts on crop yield are highly uncertain due to differences in model structure and parameter values. These specific examples illustrate there is substantial uncertainty in modeling crop and soil processes, particularly under changing environmental conditions and continuously evolving crop management practices. Likewise, when model predictions are scaled up to address regional sustainability concerns, the associated uncertainty needs to be considered (Huffman et al., 2015). A thorough review of modeling challenges is outside the scope of this article, but the reader is referred to several recent reviews highlighting these uncertainties (Benbi and Richter, 2002; Asseng et al., 2013; Vereecken et al., 2016; Brilli et al., 2017).

Ensuring the continuous availability of field data to support model improvements is itself a major challenge. To overcome this limitation, a synchronized research network would be necessary to coordinate different research programs and obtain adequate field data for continuous calibration. We propose that the core of this research network would be field experiments at agricultural universities, which are often designed to investigate the impacts of agronomic management on crop productivity but do not typically feed into modeling efforts. For the development of high resolution historical and current weather datasets, public sector partners such as the United States Department of Agriculture (USDA) Climate Hubs and the Soil Climate Analysis Network (SCAN) would be valuable partners ${ }^{1}$. In the Corn Belt of the United States, an extensive on-farm field research network such as N-Watch would be critical for development of decision support tools. The N-Watch program was started by Illinois Council on Best Management Practices analyze soil samples from farmers' fields for soil nitrate and ammonium in the corn growing season ${ }^{2}$. The dataset generated by such programs would be an important asset for calibrating model parameters against a wide variety of field data under a range of soil and climate conditions. We argue that the long-term vision proposed in this paper can only be realized by leveraging a variety of existing research efforts, particularly public-private partnerships which have made significant strides in this area.

Accompanying the challenge on the technology side, another major question is how to promote the delivery and adoption of $\mathrm{N}$ management tools among farmers. Farmer's decisions are constrained by the need to maintain farm profits, and what may be considered improved $\mathrm{N}$ management practices such as adjusting the formulation, time, rate, and placement of $\mathrm{N}$ fertilizers are voluntarily adopted in the Corn Belt of the United States (Reimer et al., 2017). Previous research has suggested that a focus on farmer education and social learning for participatory development is needed for ensuring effective delivery and adoption of decision support tools (Matthews et al., 2008; Jakku and Thorburn, 2010; Hochman and Carberry, 2011). Therefore, major emphasis would need to be placed on addressing the social difficulties associated with the adoption of new $\mathrm{N}$ management tools, for example by identifying several management options available to farmers in order to increase awareness while also providing flexibility in adopting the most effective practices to reduce environmental loss. Similarly, regardless of the target region for tool development, a critical role of $\mathrm{N}$ management tools will be their ability to maintain or enhance farm profitability while meeting $\mathrm{N}$ loss reduction goals.

\section{AUTHOR CONTRIBUTIONS}

$\mathrm{KB}$ and $\mathrm{CP}$ developed the conceptual framework and drafted the manuscript. MY assisted in reviewing existing in-season nutrient management tools. JW and EN assisted in revising the manuscript. All authors have read and approved the final manuscript.

\footnotetext{
${ }^{1}$ https://www.climatehubs.oce.usda.gov/midwest

${ }^{2}$ http://www.illinoiscbmp.org/Nitrogen-Management/N-Watch
} 


\section{REFERENCES}

Abrahamsen, P., and Hansen, S. (2000). Daisy: an open soil-crop-atmosphere system model. Environ. Modell. Softw. 15, 313-330. doi: 10.1016/S13648152(00)00003-7

Anderson, D. M., Burkholder, J. M., Cochlan, W. P., Glibert, P. M., Gobler, C. J., Heil, C. A., et al. (2008). Harmful algal blooms and eutrophication: examining linkages from selected coastal regions of the United States. Harmful Algae 8, 39-53. doi: 10.1016/j.hal.2008.08.017

Arbuckle, J. G. Jr. (2013). Farmer attitudes toward proactive targeting of agricultural conservation programs. Soc. Nat. Resour. 26, 625-641. doi: 10.1080/ 08941920.2012 .671450

Archontoulis, S. V., Miguez, F. E., and Moore, K. J. (2014). A methodology and an optimization tool to calibrate phenology of short-day species included in the APSIM PLANT model: application to soybean. Environ. Modell. Softw. 62, 465-477. doi: 10.1016/j.envsoft.2014.04.009

Asseng, S., Ewert, F., Rosenzweig, C., Jones, J. W., Hatfield, J. L., Ruane, A. C., et al. (2013). Uncertainty in simulating wheat yields under climate change. Nat. Clim. Change 3, 827-832. doi: 10.1111/gcb.13008

Bassu, S., Brisson, N., Durand, J.-L., Boote, K., Lizaso, J., Jones, J. W., et al. (2014). How do various maize crop models vary in their responses to climate change factors? Glob. Change Biol. 20, 2301-2320. doi: 10.1111/gcb. 12520

Batie, S. S. (1985). Soil conservation in the 1980s: a historical perspective. Agric. History Soc. 59, 107-123.

Benbi, D. K., and Richter, J. (2002). A critical review of some approaches to modelling nitrogen mineralization. Biol. Fertility Soils 35, 168-183. doi: 10. 1007/s00374-002-0456-6

Bergstrom, L., Johnsson, H., and Torstensson, G. (1991). Simulation of soilnitrogen dynamics using the soiln model. Fert. Res. 27, 181-188. doi: 10.1007/ BF01051126

Blackmer, A. M., Pottker, D., Cerrato, M. E., and Webb, J. (1989). Correlations between soil nitrate concentrations in late spring and corn yields in Iowa. J. Prod. Agric. 2, 103-109. doi: 10.2134/jpa1989.0103

Brilli, L., Bechini, L., Bindi, M., Carozzi, M., Cavalli, D., Conant, R., et al. (2017). Review and analysis of strengths and weaknesses of agro-ecosystem models for simulating C and N fluxes. Sci. Total Environ. 598, 445-470. doi: 10.1016/j. scitotenv.2017.03.208

Bundy, L. G., and Malone, E. S. (1988). Effect of residual profile nitrate on corn response to applied nitrogen. Soil Sci. Soc. Am. J. 52, 1377-1383. doi: 10.2136/ sssaj1988.03615995005200050032x

Cassman, K. G., Dobermann, A., and Walters, D. T. (2002). Agroecosystems, nitrogen-use efficiency, and nitrogen management. Ambio 31, 132-140. doi: 10.1579/0044-7447-31.2.132

Christianson, L. E., and Harmel, R. D. (2015). 4R water quality impacts: an assessment and synthesis of forty years of drainage nitrogen losses. J. Environ. Qual. 44, 1852-1860. doi: 10.2134/jeq2015.03.0170

Cox, H., Voil, P. D., and Rodriguez, D. (2008). "Tools to manage climate risk in cropping (Australia)," in Empowerment of the Rural Actors: A Renewal of Farming Systems Perspectives: 8th European IFSA Symposium, ClermontFerrand.

Debaeke, P., Rouet, P., and Justes, E. (2006). Relationship between the normalized SPAD index and the nitrogen nutrition index: application to durum wheat. J. Plant Nutr. 29, 75-92. doi: 10.1080/01904160500 416471

Debaeke, P., van Oosterom, E. J., Justes, E., Champolivier, L., Merrien, A., Aguirrezabal, L. A. N., et al. (2012). A species-specific critical nitrogen dilution curve for sunflower (Helianthus annuus L.). Field Crops Res. 136, 76-84. doi: 10.1016/j.fcr.2012.07.024

Decock, C., Lee, J., Necpalova, M., Pereira, E. I. P., Tendall, D. M., and Six, J. (2015). Mitigating N2O emissions from soil: from patching leaks to transformative action. Soil 1, 687-694. doi: 10.5194/soil-1-687-2015

Ewing, P. M., and Runck, B. C. (2015). Optimizing nitrogen rates in the midwestern United States for maximum ecosystem value. Ecol. Soc. 20:18. doi: 10.5751/es06767-200118

Goolsby, D. A., and Battaglin, W. A. (2001). Long-term changes in concentrations and flux of nitrogen in the Mississippi River Basin, USA. Hydrol. Process. 15, 1209-1226. doi: 10.1002/hyp.210
Grassini, P., Pittelkow, C. M., Cassmana, K. G., Yanga, H. S., Archontoulisc, S., Lichtc, M., et al. (2017). Robust spatial frameworks for leveraging research on sustainable crop intensification. Glob. Food Sec. (in press). doi: 10.1016/j.gfs. 2017.01.002

Hanson, J. D., Ahuja, L. R., Shaffer, M. D., Rojas, K. W., DeCoursey, D. G., Farahani, H., et al. (1998). RZWQM: simulating the effects of management on water quality and crop production. Agric. Syst. 57, 161-195. doi: 10.1016/S0308$521 X(98) 00002-X$

Hochman, Z., and Carberry, P. S. (2011). Emerging consensus on desirable characteristics of tools to support farmers' management of climate risk in Australia. Agric. Syst. 104, 441-450. doi: 10.1016/j.agsy.2011.03.001

Holzworth, D. P., Huth, N. I., Devoil, P. G., Zurcher, E. J., Herrmann, N. I., McLean, G., et al. (2014). APSIM - evolution towards a new generation of agricultural systems simulation. Environ. Modell. Softw. 62, 327-350. doi: 10.1016/j.envsoft.2014.07.009

Howarth, R. W. (2008). Coastal nitrogen pollution: a review of sources and trends globally and regionally. Harmful Algae 8, 14-20. doi: 10.1016/j.hal.2008.08.015

Huffman, T., Qian, B., De Jong, R., Liu, J., Wang, H., McConkey, B., et al. (2015). Upscaling modelled crop yields to regional scale: a case study using DSSAT for spring wheat on the Canadian prairies. Can. J. Soil Sci. 95, 49-61. doi: $10.4141 /$ cjss-2014-076

INLRS (2016). Illinois Nutrient Loss Reduction Strategy. Springfield, IL: Illinois Environmental Protection Agency.

IPCC (2006). N2O emissions from Managed Soils, and CO2 Emissions from Lime and Urea Application. Guidelines for National Greenhouse Gas Invertories, Chap. 11. Geneva: IPCC.

Jakku, E., and Thorburn, P. J. (2010). A conceptual framework for guiding the participatory development of agricultural decision support systems. Agric. Syst. 103, 675-682. doi: 10.1016/j.agsy.2010.08.007

Janssen, B. H., Guiking, F. C. T., Vandereijk, D., Smaling, E. M. A., Wolf, J., and Vanreuler, H. (1990). A system for quantitative-evaluation of the fertility of tropical soils (QUEFTS). Geoderma 46, 299-318. doi: 10.1016/0016-7061(90) 90021-Z

Jones, J. W., Hoogenboom, G., Porter, C. H., Boote, K. J., Batchelor, W. D., Hunt, L. A., et al. (2003). The DSSAT cropping system model. Eur. J. Agron. 18, 235-265. doi: 10.1016/S1161-0301(02)00107-7

Kim, K.-I., Clay, D. E., Carlson, C. G., Clay, S. A., and Trooien, T. (2008). Do synergistic relationships between nitrogen and water influence the ability of corn to use nitrogen derived from fertilizer and soil? Agron. J. 100, 551-556. doi: 10.2134/agronj2007.0064

Kurunc, A., Ersahin, S., Uz, B. Y., Sonmez, N. K., Uz, I., Kaman, H., et al. (2011). Identification of nitrate leaching hot spots in a large area with contrasting soil texture and management. Agric. Water Manag. 98, 1013-1019. doi: 10.1016/j. agwat.2011.01.010

Ledgard, S. F., Edgecombe, G. A., and Roberts, A. H. C. (1999). Application of the nutrient budgeting model OVERSEER to assess management options and Regional Council consent requirements on a Hawke's Bay dairy farm. Proc. N. Z. Grassl. Assoc. 61, 227-231.

Li, C. S., Frolking, S., and Frolking, T. A. (1992). A model of nitrousoxide evolution from soil driven by rainfall events.1. Model structure and sensitivity. J. Geophys. Res. Atmos. 97, 9759-9776. doi: 10.1029/ 92JD00509

Magdoff, F. (1991). Understanding the magdoff pre-sidedress nitrate test for corn. J. Prod. Agric. 4, 297-305. doi: 10.2134/jpa1991.0297

Matthews, K. B., Schwarz, G., Buchan, K., Rivington, M., and Miller, D. (2008). Wither agricultural DSS? Comput. Electron. Agric. 61, 149-159. doi: 10.1016/j. compag.2007.11.001

Melkonian, J. J., Es, H. M. V., De Gaetano, A. T., and Joseph, L. (2008). “ADAPT$\mathrm{N}$ : adaptive nitrogen management for maize using high-resolution climate data and model simulations," in Proceedings of the 9th International Conference on Precision Agriculture, Denver, CO.

Molina, J. A. E., Clapp, C. E., Shaffer, M. J., Chichester, F. W., and Larson, W. E. (1983). NCSOIL, a model of nitrogen and carbon transformations in soil - description, calibration, and behavior. Soil Sci. Soc. Am. J. 47, 85-91. doi: 10.2136/sssaj1983.03615995004700010017x

Moore, A. D., Eckard, R. J., Thorburn, P. J., Grace, P. R., Wang, E. L., and Chen, D. L. (2014). Mathematical modeling for improved greenhouse gas balances, agro-ecosystems, and policy development: lessons from the Australian 
experience. Wiley Interdiscipl. Rev. Clim. Change 5, 735-752. doi: 10.1002/ wcc. 304

Muller, C., Elliott, J., Chryssanthacopoulos, J., Arneth, A., Balkovic, J., Ciais, P., et al. (2017). Global gridded crop model evaluation: benchmarking, skills, deficiencies and implications. Geosci. Model Dev. 10, 1403-1422. doi: 10.5194/ gmd-10-1403-2017

Randall, G. W., and Mulla, D. J. (2001). Nitrate nitrogen in surface waters as influenced by climatic conditions and agricultural practices. J. Environ. Qual. 30, 337-344. doi: 10.2134/jeq2001.302337x

Reimer, A., Doll, J. E., Basso, B., Marquart-Pyatt, S. T., Robertson, G. P., Stuart, D., et al. (2017). Moving toward sustainable farming systems: insights from private and public sector dialogues on nitrogen management. J. Soil Water Conser. 72, 5A-9A. doi: 10.2489/jswc.72.1.5a

Scharf, P. C. (2015). Managing Nitrogen in Crop Production. American Society of Agronomy. Madison, WI: Crop Science Society of America, and Soil Science Society of America.

Schmitt, M. A., and Randall, G. W. (1994). Developing a soil-nitrogen test for improved recommendations for corn. J. Prod. Agric. 7, 328-334. doi: 10.2134/ jpa1994.0328

Sela, S., van Es, H. M., Moebius-Clune, B. N., Marjerison, R., MoebiusClune, D., Schindelbeck, R., et al. (2017). Dynamic model improves agronomic and environmental outcomes for maize nitrogen management over static approach. J. Environ. Qual. 46, 311-319. doi: 10.2134/jeq2016. 05.0182

Setiyono, T. D., Yang, H., Walters, D. T., Dobermann, A., Ferguson, R. B., Roberts, D. F., et al. (2011). Maize-N: a decision tool for nitrogen management in maize. Agron. J. 103, 1276-1283. doi: 10.2134/agronj2011.0053

Shanahan, J. F., Kitchen, N. R., Raun, W. R., and Schepers, J. S. (2008). Responsive in-season nitrogen management for cereals. Comput. Electron. Agric. 61, 51-62. doi: 10.1016/j.compag.2007.06.006

Sogbedji, J. M., van Es, H. M., Klausner, S. D., Bouldin, D. R., and Cox, W. J. (2001). Spatial and temporal processes affecting nitrogen availability at the landscape scale. Soil Tillage Res. 58, 233-244. doi: 10.1016/S0167-1987(00)0 0171-9

Stockle, C. O., Donatelli, M., and Nelson, R. (2003). CropSyst, a cropping systems simulation model. Eur. J. Agron. 18, 289-307. doi: 10.1016/S1161-0301(02) 00109-0

Tian, H., Lu, C., Yang, J., Banger, K., Huntzinger, D. N., Schwalm, C. R., et al. (2015). Global patterns and controls of soil organic carbon dynamics as simulated by multiple terrestrial biosphere models: current status and future directions. Glob. Biogeochem. Cycles 29, 775-792. doi: 10.1002/2014GB005021

Todd-Brown, K. E. O., Randerson, J. T., Post, W. M., Hoffman, F. M., Tarnocai, C., Schuur, E. A. G., et al. (2013). Causes of variation in soil carbon simulations from CMIP5 Earth system models and comparison with observations. Biogeosciences 10, 1717-1736. doi: 10.5194/bg-10-17 17-2013

Tomer, M. D., Porter, S. A., James, D. E., Boomer, K. M. B., Kostel, J. A., and McLellan, E. (2013). Combining precision conservation technologies into a flexible framework to facilitate agricultural watershed planning. J. Soil Water Conser. 68, 113A-120A. doi: 10.2489/jswc.68.5.113a

Tremblay, N., Bouroubi, Y. M., Belec, C., Mullen, R. W., Kitchen, N. R., Thomason, W. E., et al. (2012). Corn response to nitrogen is influenced by soil texture and weather. Agron. J. 104, 1658-1671. doi: 10.2134/agronj20 12.0184
Tremblay, N., Fallon, E., and Ziadi, N. (2011). Sensing of crop nitrogen status: opportunities, tools, limitations, and supporting information requirements. Horttechnology 21, 274-281.

USEPA (2014). Inventory of U. S. Greenhouse Gas Emissions: 1990-2013. Washington, DC: USEPA.

van Es, H. M., Czymmek, K. J., and Ketterings, Q. M. (2002). Management effects on nitrogen leaching and guidelines for a nitrogen leaching index in New York. J. Soil Water Conser. 57, 499-504.

Vereecken, H., Schnepf, A., Hopmans, J. W., Javaux, M., Or, D., Roose, D. O. T., et al. (2016). Modeling soil processes: review, key challenges, and new perspectives. Vadose Zone J. 15, 1-57. doi: 10.2136/vzj2015.09.0131

Wallach, D., and Thorburn, P. J. (2014). The error in agricultural systems model prediction depends on the variable being predicted. Environ. Modell. Softw. 62, 487-494. doi: 10.1016/j.envsoft.2014.08.001

Wang, X., Williams, J. R., Gassman, P. W., Baffaut, C., Izaurralde, R. C., Jeong, J., et al. (2012). EPIC and APEX: model use, calibration, and validation. Trans. Asabe 55, 1447-1462. doi: 10.13031/2013.42253

Wheeler, D. M., Ledgard, S. F., and DeKlein, C. A. M. (2008). Using the OVERSEER nutrient budget model to estimate on-farm greenhouse gas emissions. Aust. J. Exp. Agric. 48, 99-103. doi: 10.1071/EA07250

Xiong, W., Holman, I., Conway, D., Lin, E., and Li, Y. (2008). A crop model cross calibration for use in regional climate impacts studies. Ecol. Modell. 213, 365-380. doi: 10.1016/j.ecolmodel.2008.01.005

Yang, H. S., Dobermann, A., Lindquist, J. L., Walters, D. T., Arkebauer, T. J., and Cassman, K. G. (2004). Hybrid-maize - a maize simulation model that combines two crop modeling approaches. Field Crops Res. 87, 131-154. doi: 10.1016/j.fcr.2003.10.003

Yang, H. S., and Janssen, B. H. (2000). A mono-component model of carbon mineralization with a dynamic rate constant. Eur. J. Soil Sci. 51, 517-529. doi: 10.1046/j.1365-2389.2000.00319.x

Yuan, M. W., Couture, J. J., Townsend, P. A., Ruark, M. D., and Bland, W. L. (2016). Spectroscopic determination of leaf nitrogen concentration and mass per area in sweet corn and snap bean. Agron. J. 108, 2519-2526. doi: 10.2134/agronj2016. 05.0260

Ziadi, N., Brassard, M., Belanger, G., Claessens, A., Tremblay, N., Cambouris, A. N., et al. (2008). Chlorophyll measurements and nitrogen nutrition index for the evaluation of corn nitrogen status. Agron. J. 100, 1264-1273. doi: 10.2134/agronj2008.0016

Disclaimer: Opinions expressed are those of the authors and not necessarily those of the Illinois State Water Survey, the Prairie Research Institute, or the University of Illinois.

Conflict of Interest Statement: The authors declare that the research was conducted in the absence of any commercial or financial relationships that could be construed as a potential conflict of interest.

Copyright (c) 2017 Banger, Yuan, Wang, Nafziger and Pittelkow. This is an openaccess article distributed under the terms of the Creative Commons Attribution License (CC BY). The use, distribution or reproduction in other forums is permitted, provided the original author(s) or licensor are credited and that the original publication in this journal is cited, in accordance with accepted academic practice. No use, distribution or reproduction is permitted which does not comply with these terms. 